\title{
RESPON PENANAMAN PADI GOGO BERAS MERAH DENGAN KACANG- KACANGAN TERHADAP BERAT BERANGKASAN DAN BERAT KERING AKAR PADA KONDISI LENGAS TANAH DAN MEDIA TUMBUH BERBEDA
}

\author{
THERESIA SUZANNA CATHARINA ${ }^{1)}$, NI WAYAN PUTU MEIKAPASA ${ }^{2)}$, \\ STEVANY HANALYNA DETHAN ${ }^{3}$ ) \\ ${ }^{1,2)}$ Program Studi Agribinis Kampus Mataram UNMAS Denpasar \\ 3) Program Studi Manajemen Kampus Mataram UNMAS Denpasar
}

\begin{abstract}
e-mail : ${ }^{1)}$ theresiasca@gmail.com, ${ }^{2)}$ putumeikapasa@yahoo.co.id, ${ }^{3)}$ stevany.hanalyna.dethan@gmail.com
\end{abstract}
\begin{abstract}
ABSTRAK
Padi beras merah yang ditanam pada lahan kering perlu mendapat perhatian.Kekeringan merupakan kendala bagi peningkatan produksi pada lahan tadah hujan bahkan sawah irigasi di musim kemarau.Bagaimana bila dilakukan penanaman bersama sehingga akan lebih mudah melakukan penanaman dengan mencampur benih tanaman legum dan non legum, jika dibandingkan dengan menugalnya terpisah dalam suatu mixed cropping.

Dari hasil dan penelitan, dapat disimpulkan bahwa : penanaman bersama antara padi gogo beras merah dengan kacang-kacangan diperoleh : berat kering jerami tertinggi pada media tumbuh dari Kuripan. Panjang akar teringgi pada pemberian air $100 \%$ pada media tumbuh dari Kuripan. Berat Kering akar padi tertinggi pada media tumbuh dari Kuripan. Berat kering akar padi tertinggi dari media tumbuh dari Kuripan pada pemberian air 50\% dan luas daun lebih besar pada media tumbuh di Bayan pada pemberian air 100\%
\end{abstract}

Kata kunci : beras merah, berat berangkasan, berat kering akar, lengas tanah, media tumbuh

\section{ABSTRACT}

Red rice rice planted on dry land needs to get attention. Drought is an obstacle to increasing production on rainfed land and even irrigated fields in the dry season. What if planting is done together? it will be easier to plant by mixing legume and non-legume plants compared to blocking it apart in a mixed cropping.

From the results and research, it can be concluded that: joint planting between brown upland rice and beans is obtained: the highest dry weight of straw on growing media is from Kuripan. The highest root length at giving $100 \%$ water to the growing media comes from rice plants in Kuripan. The highest dry weight of rice roots in the growing medium is from Kuripan. Kuripan also has the highest dry weight of rice roots from the growing media with 50\% water supply and the greater leaf area on the growing media with 100\% water supply is from Bayan

Keywords: brown rice, heavy weight, root dry weight, soil moisture, growth media

\section{PENDAHULUAN}

\section{Latar Belakang}

Padi gogo merupakan salah satu ragam budidaya padi, yaitu penanaman padi di lahan kering. Lahan kering yaitu lahan yang pengairannya bergantung pada turunnya hujan atau lahan yang tidak memperoleh pengairan teknis ataupun setengah teknis (Prasetyo, 2003). 
Dari warna berasnya umumnya ada 2 jenis padi gogo, yaitu padi gogo beras putih dan beras merah. Padi beras merah, yang umumnya adalah padi gogo, sangat bermanfaat bagi kesehatan, selain manfaat utamanya sebagai makanan pokok.

Padi beras merah yang ditanam pada lahan kering perlu mendapat perhatian. Menurut Sasli (2004), kekeringan merupakan kendala bagi peningkatan produksi pada lahan tadah hujan bahkan sawah irigasi di musim kemarau.

Menurut hasil penelitian Suryani (2009), rata-rata pertumbuhan tanaman padi pada pemberian air 100\% kapasitas lapang lebih tinggi dari pada pemberian air 60\% kapasitas lapang.

Menurut Paynel et al. (2000), transfer $\mathrm{N}$ akan bermanfaat apabila sumber $\mathrm{N}$ dalam keadaan terbatas. Transfer $\mathrm{N}$ juga semakin tinggi jika jarak tanam antar legum dan non legum semakin dekat, seperti yang dilaporkan Fujita et al. (1998) bahwa laju transfer $\mathrm{N}$ tertinggi pada jarak tanam (antara kedelai dan sorgum) $12,5 \mathrm{~cm}$ dibandingkan dengan 17,5, 25 dan $50 \mathrm{~cm}$.

Pertanyaan berikutnya adalah bagaimana bila dilakukan penanaman bersama sehingga akan lebih mudah melakukan penanaman dengan mencampur benih tanaman legum dan non legum, jika dibandingkan dengan menugalnya terpisah dalam suatu mixed cropping.

Berdasarkan uraian tersebut di atas, telah dilakukan penelitian berjudul : "Respon berat berangkasan, panjang akar, berat kering akar dan luas daun padi gogo beras merah pada penanaman bersama tanaman kacang-kacangan dalam kondisi lengas tanah dan media tumbuh berbeda.

\section{Tujuan Penelitian}

Penelitan ini bertujuan untuk mengetahui respon penanaman padi gogo beras merah dengan kacangkacangan terhadap berat kering jerami dan panjang akar padi pada kondisi lengas tanah dan media tumbuh berbeda.

\section{METODE PENELITIAN}

Metode yang digunakan dalam penelitian ini adalah metode eksperimental dengan melakukan percobaan penanaman di pot. Percobaan telah dilakukan di rumah kaca yang disiapkan di lahan petani Kecamatan Mataram Kelurahan Pagutan Timur Desa Karang Buaya. Pelaksanaan percobaan direncanakan selama 4 bulan.

Rancangan percobaan yang digunakan adalah Rancangan Acak Lengkap dengan mengatur perlakuan secara faktorial, yang terdiri atas 3 faktor perlakuan sebagai berikut:

1. Asal media tumbuh (entisols) (M), dengan 3 taraf sebagai berikut :

1.1. M1 = media tumbuh dari desa Sayong

1.2. $\mathrm{M} 2=$ media tumbuh dari desa Kuripan

1.3. M3 = media tumbuh dari Bayan

2. Kombinasi tanaman dengan kacang-kacangan (K) dengan 3 taraf sebagai berikut :

2.1. $\mathrm{K} 1$ = tanaman padi (monokultur)

2.2. $\mathrm{K} 2$ = tanaman padi ditanam bersama kacang hijau

2.3. $\mathrm{K} 3$ = tanaman padi ditanam bersama kedelai

3. Kadar lengas dengan 2 perlakuan tingkat pemberian air yaitu :

3.1. $\mathrm{C} 1=$ pemberian air $100 \%$ kadar lengas.

3.2. $\mathrm{C} 2=$ pemberian air $50 \%$ kadar lengas

Dengan demikian diperoleh 18 kombinasi perlakuan dan setiap kombinasi perlakuan diulang tiga kali, sehingga diperoleh 54 pot percobaan. Untuk pengamatan mikoriza, serapan $\mathrm{N}$ dan $\mathrm{P}$ dibuat seri percobaan dengan 2 ulangan $(2 \times 18=36$ pot $)$, sehingga total keseluruhan pot adalah 90 pot.

\section{Bahan dan Alat}

Bahan-bahan yang akan digunakan adalah : Benih padi beras merah sebanyak 1 Galur harapan, benih kedelai, benih kacang hijau, tanah entisol sebagai media tumbuh yang diambil dari 3 daerah media tumbuh padi gogo yaitu media tumbuh dari Sayong, Kuripan dan Bayan, pupuk Urea, Superphos, furadan, KCl 2\%, $\mathrm{KOH} 10 \%, \mathrm{HCl} 2 \%$, Trypan blue $0,05 \%$ dan gula. 
Alat yang akan digunakan dalam penelitian ini adalah ember plastik ukuran 15 x $35 \mathrm{~cm}$, pot, ayakan, kertas label, timbangan duduk, timbangan analisis, gelas ukur, penggaris, mikroskop, oven alat tulis menulis dan leaf area meter.

\section{Pelaksanaan Percobaan}

Persiapan media tanam. Tanah Entisols yang diambil dari sawah petani di tiga lokasi penanaman padi gogo yaitu : Sayong, Kuripan dan Bayan dikeringanginkan terlebih dahulu selama satu minggu, kemudian diayak dengan menggunakan ayakan berdiameter $6 \mathrm{~mm}$ sambil dibersihkan. Tanah dianalisis laboratorium untuk mengetahui kadar lengas tanah (kadar lengas kering angin dan kadar lengas kapasitas lapangnya, titik layu permanen). Teknik penentuan kadar lengas kering angin dan kadar lengas kapasitas lapang dapat dilihat pada Lampiran 1. Setelah diketahui kadar lengasnya tanah dimasukkan ke dalam pot sebanyak $9 \mathrm{~kg} /$ pot (Lampiran 2).

Media tanam diberikan pupuk sesuai rekomendasi (Keputusan Menteri Pertanian No 01/Kpts/SR.130/I/2006 Tanggal 3 Januari 2006). Tanaman padi dipupuk sesuai dengan dosis rekomendasi. Media tanam dalam masing-masing pot diairi sampai jenuh (kadar lengas 100\%) lalu dicampur dengan $1 / 2$ dosis pupuk urea, dan seluruh dosis superphos maupun $\mathrm{KCl}$ sebagai pupuk dasar, sisa pupuk urea (setengah dosis) diberikan pada saat tanaman berumur 35 HST.

Penyiapan benih. Benih yang digunakan dalam percobaan ini adalah satu galur harapan padi beras merah, hasil hibridisasi tetua varietas Angka dan Kenya (AKBC52-16-22-13) (Aryana et al., 2006). Benih kacang hijau varietas Murai dan kedelai varietas Wilis yang digunakan adalah benih yang bersertifikat. Sebelum ditanam benih direndam selama 24 jam, kemudian langsung ditanaman di pot sesuai dengan perlakuan, tanpa disemai terlebih dahulu.

Penanaman. Benih yang telah disiapkan ditanam pada media tanam sesuai perlakuan dengan cara tanam benih langsung.

Untuk perlakuan dengan penanaman padi saja setiap pot ditanam dengan masing-masing 3 benih padi. Tanaman diperlakukan dengan pengairan kapasitas lapang sampai umur 2 minggu, lalu ditinggalkan 1 tanaman.

Untuk perlakuan dengan penanaman padi dan kacang hijau untuk setiap pot ditanam masing-masing 3 benih padi dan 3 benih kacang hijau. Tanaman diperlakukan dengan pengairan kapasitas lapang sampai umur 2 minggu, lalu ditinggalkan 1 tanaman padi dan 1 tanaman kacang hijau.

Untuk perlakuan dengan penanaman padi dan kedelai untuk setiap pot ditanam masing-masing 3 benih padi dan 3 benih kedelai. Tanaman diperlakukan dengan pengairan kapasitas lapang sampai umur 2 minggu, lalu ditinggalkan 1 tanaman padi dan 1 tanaman kedelai.

Selanjutnya tanaman diperlakukan sesuai dengan perlakuan kadar lengas.

Pemupukan. Pupuk yang digunakan, dosis dan saat aplikasinya adalah sebagai berikut :

Pupuk Urea, Superphos dan $\mathrm{KCl}$ diberikan sebagai pupuk dasar untuk semua perlakuan. Pupuk Superphos dan $\mathrm{KCl}$ diberikan sekaligus saat tanam Urea diberikan setengah dosis, sedangkan sisanya diberikan setelah tanaman berumur 35 HST yaitu:

- untuk pemupukan media tanah yang diambil dari 2 lokasi, yaitu : Sayong dan Bayan menurut lampiran spesifik lokasi Keputusan Menteri Pertanian No 01/Kpts/SR.130///2006 Tanggal 3 Januari 2006, dosisnya adalah Urea $200 \mathrm{~kg} / \mathrm{ha}$, Superphos $100 \mathrm{~kg} / \mathrm{ha}$ dan pupuk KCl $50 \mathrm{~kg} / \mathrm{ha}$, sehingga pada setiap pemberian, dosisnya adalah Urea $1 / 2 \times 0,8 \mathrm{~g} /$ pot $=0,4 \mathrm{~g} /$ pot, Superphos $0,4 \mathrm{~g} /$ pot, $\mathrm{KCl}$ 0,2 g/pot (Lampiran 3), diberikan sebagai pupuk dasar. Sisanya pupuk Urea diberikan ( $1 \frac{1}{2}$ dosis) setelah berumur 35 HST.

- untuk pemupukan media tanah yang diambil dari lokasi Kuripan menurut lampiran spesifik lokasi Keputusan Menteri Pertanian No 01/Kpts/SR.130/I/2006 Tanggal 3 Januari 2006, dosisnya adalah : Urea $200 \mathrm{~kg} / \mathrm{ha}$, Superphos $150 \mathrm{~kg} / \mathrm{ha}$ dan pupuk $\mathrm{KCl} 50 \mathrm{~kg} / \mathrm{ha}$, sehingga pada setiap pemberian, dosisnya adalah Urea $1 / 2 \times 0,8 \mathrm{~g} /$ pot $=0,4 \mathrm{~g} /$ pot, Superphos $0,6 \mathrm{~g} /$ pot, $\mathrm{KCl}$ 0,2 g/pot, diberikan sebagai pupuk dasar. Sisanya pupuk Urea diberikan (setengah dosis) setelah berumur 35 HST.

Pengairan. Pengairan dilakukan dua hari sekali dengan tingkat pemberian air 100\% kapasitas lapang dan $50 \%$ kapasitas lapang. Jumlah air yang akan diberikan diketahui dengan menghitung kadar lengas.

Penyiangan. Penyiangan dilakukan secara mekanik atau mencabut setiap gulma yang tumbuh di setiap pot percobaan. 
Pengendalian hama dan penyakit. Untuk melindungi tanaman dari gangguan hama dan penyakit maka dilakukan penyemprotan dengan menggunakan furadan sesuai dosis anjuran.

Panen. Panen dilakukan dilakukan setelah tanaman mencapai masak penuh, dengan ciri-ciri lebih dari $80 \%$ malai masak, batang kuning dan kering serta bulir padi mengeras.

\section{HASIL DAN PEMBAHASAN}

\section{Berat Berangkasan, Panjang Akar, Berat Kering Akar dan Luas Daun}

Hasil pengukuran berat berat berangkasan, panjang akar, berat kering akar dan luas daun disajikan pada Tabel 1.

Faktor media tumbuh tidak berpengaruh terhadap berat kering akar, kecuali pada berat berangkasan, panjang akar dan luas daun. Hal ini diduga karena penyerapan air tanah tergantung pada kemampuan akar menembus lapisan tanah dalam. Jumlah air yang tersedia dan unsur hara yang diserap akan berpengaruh terhadap berat berangkasan, luas daun dan panjang akar. Sistem perakaran yang baik pada tanaman padi lahan kering, adalah akar tanamannya panjang dan jumlah akar cukup banyak (O'Toole dan Chang, 1979). Tanaman padi yang ditanam dalam kondisi kering, umumnya berpengaruh terhadap pertumbuhan tanaman bila dibandingkan dengan yang ditanam di sawah (Sutrisno dan Suardi, 1989).

Tabel 1. Rerata Variabel Perlakuan Faktor Media Tumbuh, Kadar Lengas dan Kombinasi Tanaman Terhadap Berat Kering Jerami, Panjang Akar, Berat Kering Akar, dan Luas Daun.

\begin{tabular}{lllcc}
\hline & $\begin{array}{l}\text { Berat Krg } \\
\text { Jerami }(\mathrm{g})\end{array}$ & $\begin{array}{l}\text { Panjang } \\
\text { Akar }(\mathrm{cm})\end{array}$ & $\begin{array}{l}\text { Berat kering } \\
\text { Akar }(\mathrm{g})\end{array}$ & $\begin{array}{l}\text { Luas } \\
\text { Daun }\left(\mathrm{cm}^{2}\right)\end{array}$ \\
\hline Media Tumbuh & & & & \\
Sayong & $31,9 \mathrm{~b}$ & $32,36 \mathrm{~b}$ & $9,43 \mathrm{a}$ & $41,31 \mathrm{c}$ \\
Kuripan & $37,39 \mathrm{a}$ & $41,54 \mathrm{a}$ & $10,42 \mathrm{a}$ & $53,44 \mathrm{a}$ \\
Bayan & $31,74 \mathrm{~b}$ & $36,76 \mathrm{ab}$ & $9,64 \mathrm{a}$ & $45,50 \mathrm{a}$ \\
BNJ & 3,47 & 4,96 & 1,36 & 0,78 \\
Kadar Lengas & & & & \\
100\% & $31,48 \mathrm{~b}$ & $38,47 \mathrm{a}$ & $8,61 \mathrm{~b}$ & $49,00 \mathrm{a}$ \\
$50 \%$ & $35,88 \mathrm{a}$ & $35,30 \mathrm{a}$ & $11,05 \mathrm{a}$ & $44,50 \mathrm{~b}$ \\
BNJ & 2,35 & 3,36 & 0,92 & 0,52 \\
Kombinasi & & & & \\
Tanaman & $42,29 \mathrm{a}$ & $38,74 \mathrm{a}$ & $12,88 \mathrm{a}$ & $49,11 \mathrm{a}$ \\
Padi & $20,55 \mathrm{c}$ & $35,03 \mathrm{a}$ & $4,40 \mathrm{~b}$ & $43,73 \mathrm{c}$ \\
Padi+kchijau & $38,20 \mathrm{~b}$ & $36,89 \mathrm{a}$ & $12,21 \mathrm{a}$ & $47,41 \mathrm{~b}$ \\
Padi+Kedelai & 3,47 & 4,96 & 1,36 & 0,78 \\
BNJ & & &
\end{tabular}

Keterangan : Data yang diikuti huruf yang sama pada kolom yang sama pada masing-masing faktor tidak berbeda nyata pada uji lanjut Beda Nyata Jujur 5\%

Faktor kadar lengas berpengaruh terhadap berat kering jerami, berat akar dan luas daun. Hal ini diduga tanaman yang mendapatkan air terbatas dari dalam tanah sehingga tanaman akan meningkatkan volume perakaran, yang akan berpengaruh terhadap berat kering akar. Meningkatnya volume akar maka akan mempengaruhi penyerapan air dan unsur hara diantaranya unsur $\mathrm{N}$, berakibat pada berat kering jerami dan luas daun. Menurut Totok dan Ahadiyat ( 2004), cekaman kekeringan, menurunkan efisiensi penyerapan N. Widodo (2004), menyatakan pupuk $\mathrm{N}$ berpengaruh terhadap pembentukan ukuran daun untuk meningkatkan laju fotosintesis.

Faktor kombinasi tanaman berpengaruh terhadap berat kering jerami, berat kering akar dan luas daun. Hal ini diduga karena, untuk mempertahankan status air dalam tanah yaitu dengan tanaman mengurangi kanopinya dan tetap mempertahankan perkembangan ukuran akarnya sehingga mampu menyerap air, yang akan mempengaruhi luas daun, berat akar dan berat berangkasan. Menurut Suardi (2002), peranan akar dalam menyerap air tanah selama pertumbuhan menentukan kelancaran proses fotosintesis, yang akan berpengaruh pada luas daun dan berat berangkasan. 




Gambar 1. Grafik rata-rata ( \pm SE) berat kering jerami interaksi kombinasi tanaman, kadar lengas dan media tumbuh.

Berat kering jerami padi (Gambar 1), rata-rata tertinggi pada media tumbuh yang dari Kuripan. Hal ini diduga, karena unsur hara yang berada dalam tanah dapat dimanfaatkan untuk pertumbuhan dan perkembangan tanaman, demikian pula pada kondisi 50\% kadar lengas mikoriza akan membantu untuk menyerap air tersedia dan unsur hara, terutama unsur P. Menurut Ermanita et al. (2004), unsur P sangat penting dalam fotosintesa.

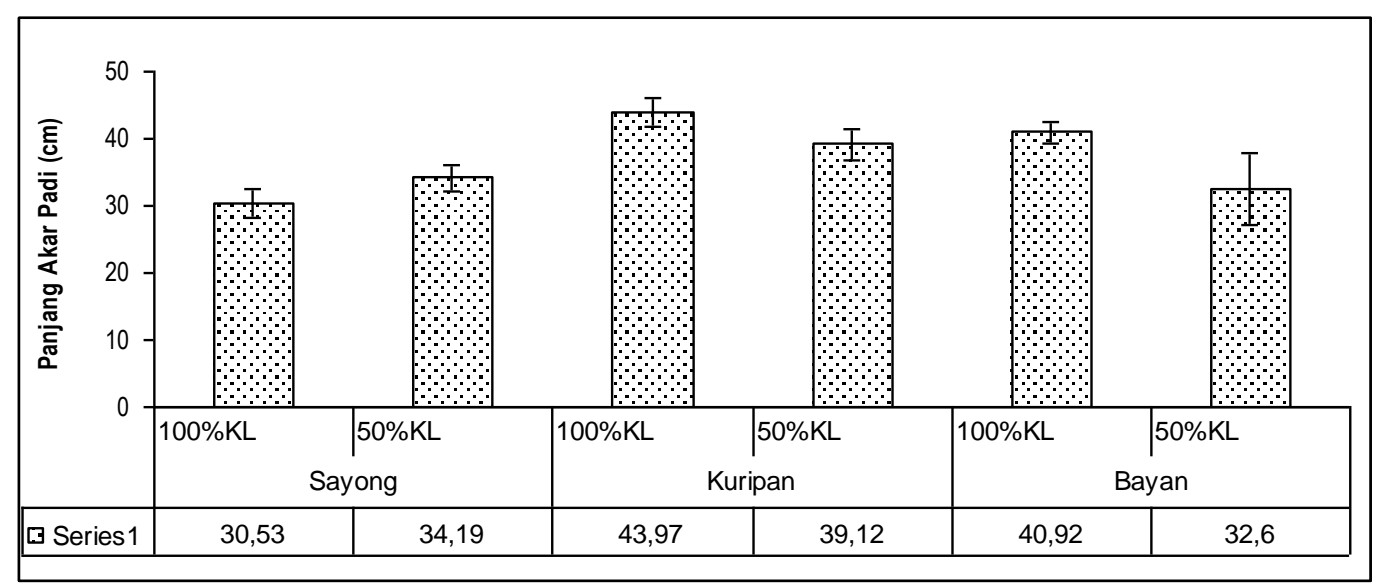

Gambar 2. Grafik rata-rata ( \pm SE) panjang akar padi pada interaksi kadar lengas dan media tumbuh.

Panjang akar padi (Gambar 2) tertinggi pada pemberian air 100\% kadar lengas pada media tumbuh yang berasal dari Kuripan dan terendah diperoleh pada pemberian air 100\% kadar lengas media tumbuh dari Sayong. Hal ini diduga karena akar tumbuh baik pada kondisi yang optimal. Menurut Suardi (2002), peran akar sangat penting karena penyerapan air tanah tergantung kemampuan akar menembus lapisan bagian bawah.

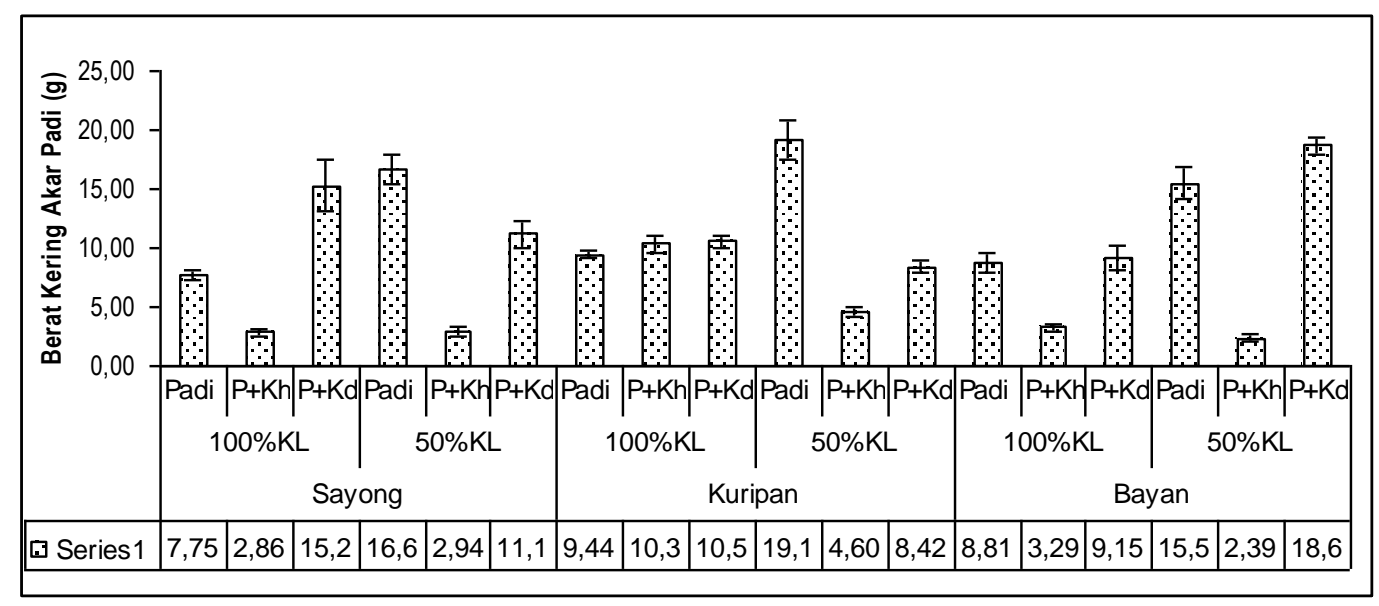

Gambar 3. Grafik rata-rata ( \pm SE) berat kering akar pada kombinasi tanaman, kadar lengas dan media tumbuh. 
Pada Gambar 3 tampak bahwa berat kering akar untuk tanaman padi yang ditanam pada kondisi pemberian air $100 \%$ kadar lengas lebih rendah dari pada kondisi pemberian air 50\% kadar lengas, hal ini diduga karena padi yang ditanam pada kondisi pemberian air 50\% kadar lengas, akan mempertahankan perkembangan ukuran akarnya sehingga mampu menyerap air, akibatnya akar tanaman akan semakin panjang pada kondisi pemberian air 50\% kadar lengas, sehingga berpengaruh pada berat kering akar. Penanaman padi dan kacang hijau serta padi dan kedelai pada kondisi pemberian air $100 \%$ kadar lengas berat kering akarnya lebih tinggi dari pada kondisi pemberian air 50\% kadar lengas Hal ini diduga karena pada kondisi pemberian air 50\% kadar lengas pada penamanan kombinasi, untuk pertumbuhan dan perkembangan tanaman membutuhkan air dan unsur hara yang lebih banyak dibandingkan dengan penanaman padi (monokultur), sehingga jumlah air dan unsur hara yang tersedia, diserap tanaman juga terbatas, akibatnya pengaruh pada berat kering akar (Gambar 2 dan 3). Menurut Suardi (2002), perakaran padi berhubungan erat dengan toleransi tanaman terhadap kekeringan.

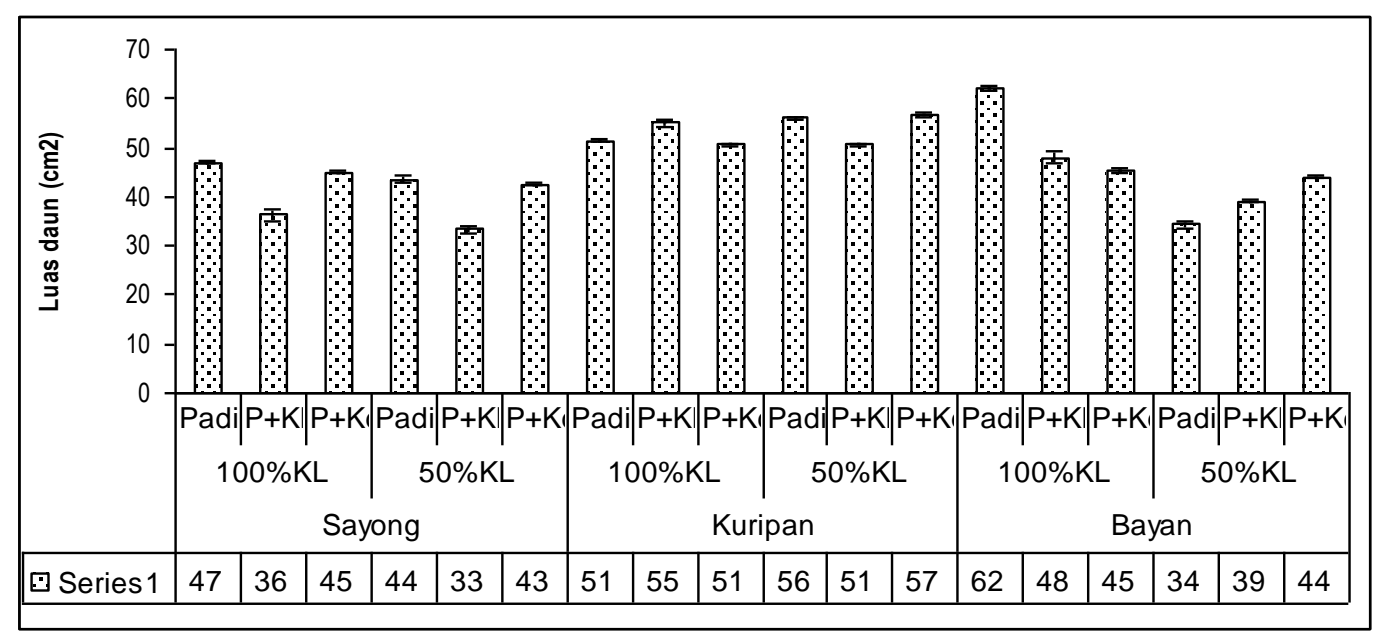

Gambar 4. Grafik rata-rata ( \pm SE) luas daun pada interaksi kombinasi tanaman, kadar lengas dan media tumbuh.

Pada Gambar 4 dapat dilihat bahwa tanaman yang di tanam pada media tumbuh di Kuripan untuk luas daun, relatif sama. Untuk media tumbuh yang berasal dari Sayong dan Bayan, luas daun pada kondisi pemberian air100\% kadar lengas, luas daunnya lebih besar dibanding dengan pemberian air 50\% kadar lengas. Hal ini diduga, karena kadar air tersedia dalam tanah, yang diserap oleh akar dapat dimanfaatkan untuk pertumbuhan tanaman diantaranya luas daun. Menurut Doorenhos dan Kassam (1979), ketersediaan air diperlukan untuk menyesuaikan diri dan digunakan untuk pertumbuhan diantaranya untuk peningkatan luas daun.

\section{SIMPULAN}

Dari hasil dan pembahasan, dapat disimpulkan bahwa : berat kering jerami tertinggi pada media tumbuh dari Kuripan. Panjang akar teringgi pada pemberian air $100 \%$ pada media tumbuh dari Kuripan. Berat Kering akar padi tertinggi pada media tumbuh dari Kuripan. Berat kering akar padi tertinggi dari media tumbuh dari Kuripan pada pemberian air 50\% dan luas daun lebih besar pada media tumbuh di Bayan pada pemberian air $100 \%$ 


\section{DAFTAR PUSTAKA}

Dewi, I.R.A., 2009. Fiksasi N Biologis pada Ekosistem (Tugas Makalah Mata Kuliah Biofertilisasi). http://pustaka.unpad.ac.id/wp-content/uploads/2009/06/rhizobia_mklh_1.pdf. diakses tanggal 8 Juni 2009.

Doorenbos, V. and A. Kassam, 1979. Yield Respons to Water. Irrigation and Drainage Paper No. 33. FAO. Roma

Ermanita, Y. Bey dan Firdaus L.N., 2004. Pengaruh Vegetatif Dua Varietas Jagung pada Tanah Gambut yang diberi Limbah Pulp dan Paper. Jurnal Biogenesis 1(1) : 1-8.

O'Toole and Chang, 1979. Drought Resistance in Cereal Rice: a case study in mussel and han. R.c. Staples (Eds) Stress Physiology in crop plants, John Willy and Son, New York. P 374-487.

Paynel, F., L. Fabien, J. Bigot, S. Diquelou and B. J. Cliquet, 2008. A Study of N Transfer Between Legumes and Grasses. http://www.agronomy-journal.org/index.php?option=article\&access=... Diakses tanggal 5 Oktober 2009.

Prasetyo, Y.T., 2003. Bertanam Padi Gogo Tanpa Olah Tanah.. Penebar Swadaya. Jakarta

Sasli, I., 2004. Peranan Mikoriza Vesikula Arbuskula (MVA) terhadap cekaman kekeringan. http://rudyct.com/PPS702-ipb/08234/iwan_sasli_pdf. diakses 17 Mei 2009.

Suardi, D.K., 2002. Perakaran Padi dalam Hubungannya dengan Toleransi Tanaman terhadap Kekeringan dan Hasil. Jurnal Litbang Pertanian, 21 (3) : 100-108

Suardi, D.K., 2005. Potensi Beras Merah Untuk Meningkatkan Mutu Pangan. http://www.pustakadeptan.go.id/ diakses tanggal 18 Mei 2009.

Suryani, N., 2009. Sensitivitas 10 Varietas Padi (Oryza sativa L.) terhadap Kondisi Stress Air. Skripsi. Mataram.

Totok, A.D.H. dan A.Y. Rahayu, 2004. Analisis Efisiensi Serapan N, Pertumbuhan dan Hasil beberapa Kultivar Kedelai Unggul Baru dengan Cekaman Kekeringan dan Pemberian Pupuk Hayati. Jurnal Agrosains 6 (2): 70-74.

Widodo, 2004. Tanggapan Lima Kultivar Padi Lokal Rawa Gambut terhadap Aplikasi Kombinasi Dosis Pupuk Urea, SP-36 dan KCl. Jurnal Akta Agrosia 7 (2) : 41-46. 